\title{
The dispersal capacity of vegetative propagules of riparian fen species
}

\author{
J. M. Sarneel
}

Received: 23 June 2011/Accepted: 5 February 2012/Published online: 2 March 2012

(C) The Author(s) 2012. This article is published with open access at Springerlink.com

\begin{abstract}
Flowing water can disperse a high number of seeds and vegetative propagules over long distances and is therefore a very important dispersal vector in wetland habitats. Although the dispersal of seeds is relatively well studied, the dispersal of vegetative propagules has received less attention. However, in riparian and aquatic systems where many species have clonal growth forms, it can be very important. The relative importance of vegetative propagules in the dispersal of fen species was assessed first by determining their relative abundance in the field and second, by determining the buoyancy of plant fragments of ten fen species experimentally. On average, vegetative propagules made up $3.2-58.9 \%$ of the total propagule number (mainly Elodea nutallii). Buoyancy of the tested species ranged from 25 days to over 6 months. Surprisingly, the propagules of Stratiotes aloides and Hydrocharis morsus-ranae increased
\end{abstract}

Guest editors: Zhengwen Liu, Bo-Ping Han \& Ramesh D. Gulati / Conservation, management and restoration of shallow lake ecosystems facing multiple stressors

J. M. Sarneel

Ecology and Biodiversity Group, Utrecht University, P.O.Box 80084, 3508, TB, Utrecht, The Netherlands

J. M. Sarneel (ه)

Department of Aquatic Ecology, Netherlands Institute of Ecology, Droevendaalsesteeg 10, 6708, PB, Wageningen, The Netherlands

e-mail: j.sarneel@nioo.knaw.nl buoyancy when spring started (after ca. 100 days). The results demonstrate that vegetative propagules of riparian and aquatic fen species have a high capacity to disperse over long distances via water and are therefore likely to play an important role in the colonisation of new habitats. Especially because in nine out of the ten species tested, over $50 \%$ of the propagules were still viable after 6 months of floating.

Keywords Buoyancy · Clonal growth · Dispersal · Hydrochory $\cdot$ Trait $\cdot$ Water body

\section{Introduction}

Dispersal via water (hydrochory) provides an efficient dispersal method for many aquatic, riparian and even terrestrial species (Boedeltje et al., 2003; Sarneel, 2010; Rouifed et al., 2011). It is generally acknowledged that besides dispersal via seeds, dispersal via a broad variety of vegetative plant parts provides an important alternative dispersal mode. This was established by numerous observations of viable plant fragments collected in seed traps in rivers (Eber, 1983; Klosowski et al., 1995; Haraguchi, 1996; Smolders et al., 1995; Boedeltje et al. 2003; Riis \& Sand-Jensen, 2006; Vogt, personal communication) but only a few studies investigated vegetative dispersal via propagules experimentally (Johansson \& Nilsson, 1993; Xie et al., 2010). 
The nature of vegetative propagules is diverse, but usually, any plant fragment that disperses and is capable of resprouting when it meets a favourable habitat after dispersal is considered to be a vegetative propagule (Barrat-Segretain, 1996). Vegetative propagules can be rhizomes, stolons, tubers, turions, simple stem or leaf fragments or even entire plants. Those are often formed by accident (e.g. herbivory, disturbances or management activities such as mowing or dredging), but they can also form spontaneously (BarratSegretain, 1996; Xie et al., 2010). Although literature on actual dispersal distances of vegetative propagules is scarce, hydrochory has been reported to transport vegetative propagules over distances between $20 \mathrm{~m}$ and $5.4 \mathrm{~km}$ (Johansson \& Nilsson, 1993; Boedeltje et al., 2003; Riis \& Sand-Jensen, 2006; Thomas et al., 2006). Part of the variation in those dispersal distances can be attributed to differences in flow and hydrology of the studied water bodies. However, variation in species traits, such as buoyancy and physical appearance (e.g. length), may also play a role (Riis \& SandJensen, 2006; Kleyer et al., 2008), but how and when remains anecdotal.

A suitable system to study the dispersal of vegetative propagules is the fen wetland. In the riparian zones of fens, a large proportion of plant species have clonal growth forms and a high proportion of air filled tissue (aerenchyma). Therefore, any plant fragment may have a high probability of dispersal by floating and to resprouting upon stranding. Hence, vegetative propagules might form an important dispersal strategy for those species. Several species such as Calla palustris L., Hydrocharis morsus-ranae L. and Stratiotes aloides L. even produce specialized vegetative propagules that detach easily (for a description see the methods section). Therefore, it can be hypothesised that a high number of plant species are dispersed via vegetative propagules in fen ponds via water.

Buoyancy of plant propagules is considered a main determinant for dispersal by water. It is reasoned that prolonged buoyancy favours long distance dispersal, especially in systems like fens that are characterised by slow flowing water. Therefore, it can be hypothesised that the buoyancy of vegetative propagules from fen species is high.

To assess the relative importance of vegetative propagules in the dispersal of fen species the following questions were addressed:
1. What proportion of the total number of propagules that is deposited on banks in fen ponds consists of vegetative propagules? How does this vary in time and space?

2. What is the buoyancy of propagules of fen species? And are those vegetative propagules still able to germinate after prolonged time in the water?

\section{Methods}

Deposition measurements

To determine the temporal and spatial variation in the dispersal of vegetative propagules, the following design was chosen. During November 2006 and February, May and August 2007, two $50 \times 50 \mathrm{~cm}$ seed traps (cf. Wolters et al., 2004), in the form of artificial grass mats (Eijkelkamp agrisearch equipment $\mathrm{BV}$, Giesbeek) were installed at the waterline in four ponds in De Westbroekse Zodden $\left(52^{\circ} 10 \mathrm{~N} ; 5^{\circ} 07 \mathrm{E}\right)$ fen reserve. In November 2007, two mats were installed in eight ponds, including those sampled before. In fens, dispersal of seeds follows the main wind direction (Soomers et al., 2010; Sarneel, 2010). As the dominant wind direction is SW (Royal Netherlands Meteorological Institute), banks at the NE and SW ends of the ponds are likely to receive different propagule inputs. Therefore, one mat was installed at the NE and one at the SW bank of each sampled pond (two mats per pond). After 4 weeks, the mats were collected from the field and thoroughly rinsed.

The seeds and vegetative propagules in the trapped material were counted and identified using Van der Meijden (2005) and Cappers et al. (2006). Whole plants (e.g. Lemna species) were considered viable propagules. Fragments of Elodea nutallii were considered viable when they were green and consisted of at least three internodes. Any green plant fragment with roots or meristem(s) and any rhizome or stolon fragment was considered a potential vegetative propagule and therefore assessed for its viability via a germination trial (Boedeltje et al., 2003). Those fragments were planted in $10 \times 10 \mathrm{~cm}$ pots filled with potting soil and placed in a greenhouse $\left(20-30^{\circ} \mathrm{C}\right.$; $16 \mathrm{H}$ photoperiod). The pots were watered regularly. A 
Table 1 Characteristics of the propagules in the buoyancy experiment

\begin{tabular}{|c|c|c|c|c|c|c|}
\hline & $N$ & $\begin{array}{l}\text { Propagule } \\
\text { weight } \\
(\mathrm{g}) \pm \mathrm{SE}\end{array}$ & $\begin{array}{l}\text { Propagule } \\
\text { length } \\
(\mathrm{cm}) \pm \mathrm{SE}\end{array}$ & $\begin{array}{l}\text { Resprouting } \\
(\%)\end{array}$ & $\begin{array}{l}\text { Buoyancy } \\
\text { (\% floating } \\
\text { after } 187 \text { days) }\end{array}$ & Propagule type \\
\hline Acorus calamus & 6 & $42.08 \pm 13.19$ & $18 \pm 5.1$ & 58.3 & 100 & $\begin{array}{l}\text { Solid, thick rhizome with } \\
\text { sprouts. }\end{array}$ \\
\hline Calla palustris & 50 & n.d. & n.d. & 72.0 & 100 & Specialized organ $^{\mathrm{a}}$ \\
\hline Comarum palustre & 20 & $4.72 \pm 0.53$ & $18.2 \pm 1.4$ & 92.9 & 50 & $\begin{array}{l}\text { Woody rhizome with leaves } \\
\text { and growth tip }\end{array}$ \\
\hline Equisetum fluviatile & 20 & $6.94 \pm 1.59$ & $44.2 \pm 3.0$ & 69.2 & 92.8 & $\begin{array}{l}\text { Hollow rhizome with } \\
\text { sprouts }\end{array}$ \\
\hline $\begin{array}{l}\text { Hydrocharis morsus- } \\
\text { ranae }\end{array}$ & 50 & n.d. & n.d. & 100 & 100 & Specialized organ ${ }^{b}$ \\
\hline Mentha aquatic & 19 & $2.24 \pm 0.31$ & $22.4 \pm 1.9$ & 58.3 & 76.9 & $\begin{array}{l}\text { Stem fragment of creeping } \\
\text { stem }\end{array}$ \\
\hline Menyanthes trifoliate & 15 & $10.16 \pm 1.64$ & $14.6 \pm 1.7$ & 69.2 & 100 & $\begin{array}{l}\text { Stem fragment of creeping } \\
\text { stem }\end{array}$ \\
\hline Phragmites australis & 20 & $26.15 \pm 5.45$ & $30.6 \pm 4.4$ & 35.7 & 57.1 & $\begin{array}{l}\text { Hollow rhizome with roots } \\
\text { and sprouts }\end{array}$ \\
\hline Stratiotes aloides & 50 & n.d. & n.d. & 84.0 & 92.0 & Specialized organ $^{c}$ \\
\hline Thelypteris palustris & 20 & $8.54 \pm 1.30$ & $24.9 \pm 2.8$ & 57.1 & 0.0 & $\begin{array}{l}\text { Woody rhizome with } \\
\text { growth tips }\end{array}$ \\
\hline
\end{tabular}

\footnotetext{
${ }^{\text {a }}$ Vegetative propagules consist of $<5 \mathrm{~cm}$ long rhizome branches that detach easily upon touching (Eber, 1983). The top of such buds forms new leaves upon resprouting. Roots are formed much later

b Vegetative propagules consist of buds ( $\pm 1 \mathrm{~cm}$ long) that are formed at the end of stolons. Those buds consist of tiny folded leaves that detach easily and unfold upon resprouting

c Vegetative propagules are formed as axillary buds. When the bottom leaves of the rosette decay, these buds are released. On average $4.7( \pm 0.28 \mathrm{SE})$ buds are formed per mature rosette $(n=83)$
}

fragment was considered viable and thereby a vegetative propagule when it formed new roots, shoots or leaves within 8 weeks.

The differences in the number of vegetative propagules were compared between upwind and downwind banks with use of a repeated measures test, regarding both sides of each pond as the within-subject factor. The months were analysed at the between subject factor because only a weak coupling between the months was expected. To increase homogeneity of variance, the numbers of vegetative propagules were ln +1 transformed. All statistical analyses were performed in PASW statistics (version 18.0).

\section{Buoyancy measurements}

Vegetative propagules of ten species (Acorus calamus L., Calla palustris L., Comarum palustre L., Equisetum fluviatile L., Hydrocharis morsus-ranae L., Mentha aquatica L., Menyanthes trifoliata L., Phragmites australis (Cav.) Steud., Stratiotes aloides L. and Thelypteris palustris Schott.) were collected from the field at the end of September 2006. Only free-floating rhizome and plant fragments were collected (Table 1 for a description per species). Those fragments had not been afloat long before collection as most likely, the majority of the collected fragment had been formed by the dredging activities a few days before.

Calla, Hydrocharis and Stratiotes produce specially adapted vegetative propagules and these were collected directly from the plant, from at least three populations. Calla forms $\pm 5 \mathrm{~cm}$ long rhizome branches that detach easily upon touching (Eber, 1983). The top of such buds forms new leaves upon resprouting. Roots are formed in a later phase. Hydrocharis plants produce stolons with new plants and every now and then stolons that bear cone-shaped buds $( \pm 1 \mathrm{~cm}$ long) instead of new plants. Those buds detach easily and consist of tiny folded leaves. In spring, the leaves of these buds unfold one by one. In 
Fig. 1 Percentage of the propagules of the different species that remained floating between 11 October 2006 and 13 April 2007 (left axis) and temperature changes over time (right axis). Species names are abbreviated as the first three letters of the generic and species name. Full names can be found in Table 1

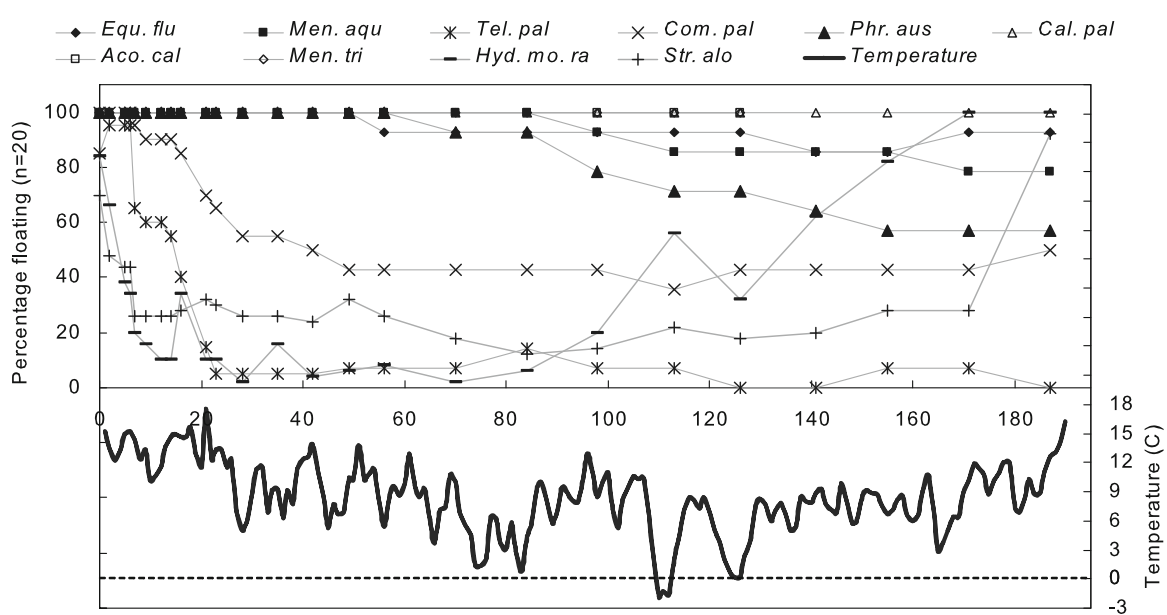

Stratiotes, vegetative propagules are formed as axillary buds ( $\pm 3-5 \mathrm{~cm}$ long). When the bottom leaves of the mother rosette decay, these buds are released. About $4.7( \pm 0.28 \mathrm{SE} ; n=83)$ buds are formed per mature rosette.

In the lab, the length and the fresh weight of each propagule was determined. For the species with large propagules, large containers $(50 \times 50 \mathrm{~cm})$ were filled with rainwater to a depth of $60 \mathrm{~cm}$ on the 11th of October 2006. The containers were placed in an unheated greenhouse where temperatures followed the outdoor situation (Fig. 1). Per container, three propagules of different species were added (random combinations). Per species, 20 propagules were put afloat in the containers (each propagule being accompanied by the propagules of two other species). For Acorus, only six propagules were tested as no more propagules could be collected. With this experimental set up, the floating behaviour and development of each separate propagule could be followed. The small propagules of Calla, Hydrocharis and Stratiotes would have been lost in the large containers. Therefore, 50 propagules of those species placed in ten separate plastic pots $\left(19 \times 12.5 \mathrm{~cm}^{2} ; 5\right.$ propagules per pot) which were filled to a water depth of $8 \mathrm{~cm}$.

Each week, the water in the containers and the pots was stirred by making three circles with a long wooden stake (and a smaller one for the small pots) to mimic natural turbulence. After that, the number of sunken propagules was recorded. The large propagules were recorded 'sunk' when they reached a water depth of $50 \mathrm{~cm}$ or more. In the smaller pots, the number of propagules that reached the bottom was recorded with the same time interval. After 6 months all propagules (except for the aquatic species Stratiotes and Hydrocharis) were taken from the containers and per species, ten propagules were tested for viability. The propagules were planted in trays $(395 \times 430 \times 75 \mathrm{~mm})$ in the greenhouse $\left(20-30^{\circ} \mathrm{C}\right)$. The trays were filled with potting soil and watered regularly. If new roots, stems or leaves were formed within 1 month, the propagule was considered to be viable.

As the data were not normally distributed, a Kruskal-Wallis test was performed to compare the final frequency of sinking and resprouting between the different species. Because of the low number of replicates, Acorus was discarded from this analysis. To test if there was a relation between resprouting and sinking, averaged germination and floating percentages of the species were correlated via a Spearman correlation.

\section{Results}

\section{Deposition}

The total number of vegetative propagules varied enormously between the sampled ponds and the sampling periods (Table 2). Highest numbers of vegetative propagules were found at downwind pond ends (repeated measures, within-subjects effect; $F_{1,19}=40.25 ; P<0.001$ ) and in winter (betweensubjects effect; $F_{4,19}=12.05 ;$ n.s.). A large number of propagules trapped were from the submerged and floating aquatic species Elodea nutallii and Lemna 
Table 2 Mean number of vegetative propagules found in the seed traps $(50 \times 50 \mathrm{~cm})$ and their proportion of the total amount of propagules on NE and SW pond ends

\begin{tabular}{|c|c|c|c|c|c|}
\hline \multirow[t]{2}{*}{ Month } & \multirow[t]{2}{*}{ Pond side $(n)$} & \multicolumn{2}{|c|}{ Total number of vegetative propagules } & \multicolumn{2}{|c|}{ Proportion vegetative propagules $(\%)$} \\
\hline & & Mean & SE & Mean & SE \\
\hline \multirow[t]{2}{*}{ Nov-06 } & SW (4) & 24.0 & 12.7 & 8.7 & 4.4 \\
\hline & NE (4) & 4576.0 & 2283.5 & 55.2 & 22.0 \\
\hline \multirow[t]{2}{*}{ Feb-07 } & SW (4) & 13.3 & 9.8 & 13.5 & 11.5 \\
\hline & NE (4) & 3633.0 & 3269.5 & 58.9 & 22.6 \\
\hline \multirow[t]{2}{*}{ May-07 } & SW (4) & 91.5 & 86.2 & 8.3 & 6.2 \\
\hline & NE (4) & 141.0 & 108.2 & 31.2 & 16.6 \\
\hline \multirow[t]{2}{*}{ Aug-07 } & SW (4) & 9.0 & 5.0 & 3.2 & 2.7 \\
\hline & NE (4) & 111.5 & 53.9 & 29.0 & 18.1 \\
\hline \multirow[t]{2}{*}{ Nov-07 } & SW (8) & 376.6 & 196.8 & 25.8 & 9.7 \\
\hline & NE (8) & 1907.0 & 876.7 & 37.5 & 12.1 \\
\hline
\end{tabular}

Because dispersal in fen ponds is driven by wind, which in the Netherlands comes predominantly from SW, NE and SW banks represent two sites with contrasting propagule input

minor L. (up to 13,372 and 6,222 propagules and on average 66 and $14 \%$ of the vegetative propagules, respectively). The most frequent emergent macrophytes found were Sparganium species, Mentha aquatica and Glyceria maxima (Hartm.) Holmb.

The average proportion of vegetative propagules trapped in the mats ranged from 3.2 to $58.9 \%$ (Table 2). At downwind NE banks, the proportion of vegetative propagules was significantly larger (Within-subjects effect; $F_{1,19}=20.14 ; P<0.001$ ) but the proportion did not differ between the months (Between-subjects effect; $F_{4,19}=0.48$; n.s.).

Buoyancy

The ten selected species differed significantly in their ability to float (Fig. $1 ; \chi^{2}=54.42 ; P<0.001$ ). Propagules of Hydrocharis and Stratiotes were the first to sink, followed by the woody stem fragments of Comarum and Thelypteris. Sinking was a relatively gradual as the propagules of these species took several days or even a week to reach the bottom of the container. After about 100 days, the first rhizomes of Phragmites started to rot and sank, followed by the slender-rhizome species Mentha and Equisetum that also disintegrated. All thick rhizomes of Acorus and Menyanthes and the propagules of Calla remained buoyant over the entire 6 months.

Surprisingly, the propagules of Stratiotes and Hydrocharis increased buoyancy after about 100 days, when spring started and temperatures rose. Almost all propagules of these species were floating again at the end of the experiment (Fig. 1). In both species, leaves were formed when they started to float again.

In Calla, $72 \%$ of the propagules started to form tiny leaflets during the experiment. The viability of the propagules of the other species was generally high (Table 1). Mentha had the lowest resprouting percentage (36\%), followed by Comarum, Acorus, Equisetum and Menyanthes (57, 58, 67 and 69\%, respectively). Thelypteris and Phragmites had the highest percentage of budding rhizomes (73 and 98\%, respectively). Overall, resprouting was not significantly correlated to buoyancy.

\section{Discussion and conclusions}

Several findings of this study demonstrate that vegetative propagules form an important dispersal mode in fen ponds. First, high numbers of vegetative propagules are dispersed by hydrochory, especially during the winter months. In rivers, Cellot et al. (1998) found that the number of vegetative propagules in the water increased by flooding as greater turbulence caused more fragmentation of aquatic and riparian plants. In the ponds of this study, the increased number of vegetative propagules in autumn and winter can most likely be explained by natural decay of (submerged) macrophytes and the increased turbulence in the water 
by stronger winds as they were not dredged. Second, vegetative propagules are important as they often form a large proportion of the total amount of floating propagules (up to $58.9 \%$ ). Third, for nine out of ten tested species, $50 \%$ or more were still floating after 6 months, which leads to the conclusion that vegetative propagules of fen species are well adapted to (long distance) dispersal via water. These floating times are high compared to floating times of seeds. In the Leda trait-base reliable buoyancy data are available for 778 species (Kleyer et al., 2008). For 313 species, over $50 \%$ of the seeds have already sunk after just 1 week.

Some species (Hydrocharis and Stratiotes) regained buoyancy in spring. This behaviour is known for adult Stratiotes plants and is probably associated to photosynthetic activity in the leaves (Westhoff et al., 1971). Apparently, juvenile Stratiotes and Hydrocharis show the same annual fluctuation. This regaining of buoyancy might lead to an underestimation of their dispersal capacity in short term experiments and might have an important ecological meaning as it allows floating propagules to escape freezing in winter.

Although buoyancy is a very important trait that determines the probability of a vegetative propagule to colonise new, distant habitats, other propagule traits such as size, shape, tissue density and the ability to resprout easily are also important. Johansson \& Nilsson (1993) and Riis \& Sand-Jensen (2006) found that the physical form of vegetative propagules determined the probability of stranding behind obstacles (e.g. vegetation patches) and thereby the actual dispersal distances in Ranunculus lingua, Elodea canadensis and Ranunculus peltatus. In submerged macrophytes, resprouting depends on habitat characteristics (light and nutrients; Barrat-Segretain, 2004; Xie et al., 2010) and differs between species. Invasive submerged macrophytes are thought to resprout more easily and expand faster afterwards compared to native species (Xie et al., 2010). This implies that care should be taken during management activities that can create vegetative propagules of invasive species such as dredging and harvesting as those fragments may disperse and colonise other habitats.

Because this study showed that a large proportion of the propagules were still viable after 6 months in the water, it is likely that floating vegetative propagules are highly effective for long distance dispersal and new colonisation events on fen banks. Especially because the colonisation of fen banks and ponds by seeds is often hampered, either because the propagule bank does not contain many species (Sarneel, 2010; Bakker et al., 2012) or because germination and establishment are hampered (Sarneel \& Soons, 2011).

Acknowledgments Merel Soons, Boudwijn Beltman, Jonne Hartman and Jos Verhoeven are acknowledged for their theoretical input and critical comments, Fred Siesling for practical assistance in the greenhouse and State Forestry for allowing entrance to their nature reserves. This study was conducted within the National Research Programme 'Ontwikkeling + Beheer Natuurkwaliteit', funded by the Dutch Ministry of Agriculture, Nature and Food Quality.

Open Access This article is distributed under the terms of the Creative Commons Attribution License which permits any use, distribution, and reproduction in any medium, provided the original author(s) and the source are credited.

\section{References}

Bakker, E. S., J. M. Sarneel, R. D. Gulati, Z. Liu \& E. Van Donk, 2012. Restoring macrophyte diversity in shallow temperate lakes: biotic vs. abiotic contraints. Hydrobiologia (this issue).

Boedeltje, G., J. P. Bakker, R. M. Bekker, J. M. Van Groenendael \& M. Soesbergen, 2003. Plant dispersal in a lowland stream in relation to occurrence and three specific lifehistory traits of the species in the species pool. Journal of Ecology 91: 855-866.

Barrat-Segretain, M. H., 1996. Strategies of reproduction, dispersion, and competition in river plants: a review. Vegetatio 123: 13-37.

Barrat-Segretain, M. H., 2004. Growth of Elodea canadensis and Elodea nuttallii in monocultures and mixture under different light and nutrient conditions. Archiv für Hydrobiologie 161: 133-144.

Cappers, R. T. J., R. M. Bekker \& J. E. A. Jans, 2006. Digitale Zadenatlas van Nederland. Barkhuis Publishing, Groningen.

Cellot, B., F. Mouillot \& C. P. Henry, 1998. Flood drift and propagule bank of aquatic macrophytes in a riverine wetland. Journal of Vegetation Science 9: 631-640.

Eber, W., 1983. Untersuchungen zur populationsbiologie von Calla palustris L. Tuexenia 3: 417-421.

Haraguchi, A., 1996. Rhizome growth of Menyanthes trifoliata $\mathrm{L}$ in a population on a floating peat mat in Mizorogaike pond, central Japan. Aquatic Botan 53: 163-173.

Johansson, M. E. \& C. Nilsson, 1993. Hydrochory, populationdynamics and distribution of the clonal aquatic plant Ranunculus lingua. Journal of Ecology 81: 81-91.

Kleyer, M., R. M. Bekker, I. C. Knevel, J. P. Bakker, K. Thompson, M. Sonnenschein, P. Poschlod, J. M. Van Groenendael, L. Klimes, J. Klimesová, S. Klotz, G. M. Rusch, M. Hermy, D. Adriaens, G. Boedeltje, B. Bossuyt, A. Dannemann, P. Endels, L. Götzenberger, J. 
G. Hodgson, A.-K. Jackel, I. Kühn, D. Kunzmann, W. A. Ozinga, C. Römermann, M. Stadler, J. Schlegelmilch, H. J. Steendam, O. Tackenberg, B. Wilmann, H. J. C. Cornelissen, O. Eriksson, E. Garnier \& B. Peco, 2008. The LEDA Traitbase: a database of life-history traits of Northwest European flora. Journal of Ecology 96: 1266-1274.

Klosowski, S., H. Tomaszewicz \& G. Tomaszewicz, 1995. Standortsbedingungen des Calletum palustris, Menyantheum trifoliatae und potentilletum palustris in NordostPolen. Tuexenia 15: 205-219.

Riis, T. \& K. Sand-Jensen, 2006. Dispersal of plant fragments in small streams. Freshwater Biology 51: 274-286.

Rouifed, S., S. Puijalon, M. R. Viricel \& F. Piola, 2011. Achene buoyancy and germinability of the terrestrial invasive Fallopia $\times$ bohemica in aquatic environment: a new vector of dispersion? Ecoscience 18: 79-84.

Smolders, A. J., C. Den Hartog \& J. G. Roelofs, 1995. Observations on fruiting and seed-set of Stratiotes aloides L. in The Netherlands. Aquatic Bot 51: 259-268.

Sarneel, J. M., 2010. Colonisation processes in riparian fen vegetation, PhD dissertation, Utrecht University, Utrecht.

Sarneel, J. M. \& M. B. Soons, 2011. Post-dispersal probability of germination and establishment on the shorelines of slow-flowing or stagnant water bodies. Journal of Vegetation Science. doi:10.1111/j.1654-1103.2011.01367.x.

Soomers, H., D. N. Winkel, Y. Du \& M. J. Wassen, 2010. The dispersal and deposition of hydrochorous plant seeds in drainage ditches. Freshwater Biology 55: 2032-2046.

Thomas, J. R., B. Middleton \& D. J. Gibson, 2006. A landscape perspective of the stream corridor invasion and habitat characteristics of an exotic (Dioscorea oppositifolia) in a pristine watershed in Illinois. Biological Invasions 8: 1103-1113.

Van der Meijden, R., 2005. Heukels' Flora van Nederland Drieëntwintigste Druk. Wolters-Noordhoff, Groningen.

Wolters, M., J. Geertsema, E. R. Chang, R. M. Veeneklaas, P. D. Carey \& J. P. Bakker, 2004. Astroturf seed traps for studying hydrochory. Functional Ecology 18: 141-147.

Westhoff, V., P. A. Bakker, C. G. Van Leeuwen \& E. E. Van der Voo, 1971. Wilde planten: flora en vegetatie in onze natuurgebieden Deel 2. De lange/Van leer, Deventer.

Xie, D., D. Yu, L. F. Yu \& C. H. Liu, 2010. Asexual propagations of introduced exotic macrophytes Elodea nuttallii, Myriophyllum aquaticum, and $M$. propinquum are improved by nutrient-rich sediments in China. Hydrobiologia 655: 37-47. 